\title{
Evaluation of antibiotic activity produced by Pseudomonas aeruginosa LV strain against Xanthomonas arboricola pv. pruni
}

\author{
Fernanda Corrêa da Silva Vasconcellos ${ }^{1}$, Admilton Gonçalves de Oliveira ${ }^{1}$, \\ Lucilene Lopes-Santos ${ }^{1}$, Jamile Priscila de Oliveira Beranger ${ }^{1}$, Martha Viviana Torres Cely ${ }^{1}$, \\ Ane Stefano Simionato ${ }^{1}$, Juliana Fonteque Pistori ${ }^{1}$, Flavia Regina Spago ${ }^{1}$, \\ João Carlos Palazzo de Mello ${ }^{2}$, Juca Abramo Barrera San Martin ${ }^{3}$, \\ Celia Guadalupe Tardeli de Jesus Andrade ${ }^{3}$, Galdino Andrade ${ }^{1^{\star}}$

\footnotetext{
${ }^{1}$ Departamento de Microbiologia, Laboratório de Ecologia Microbiana, Universidade Estadual de Londrina, Londrina, Brazil;

*Corresponding Author: andradeg@uel.br

${ }^{2}$ Departamento de Farmácia e Farmacologia, Laboratório de Produtos Fitoterápicos, Universidade Estadual de Maringá, Maringá, Brazil

${ }^{3}$ Departamento de Biologia Geral, Laboratório de Microscopia e Microanálise, Universidade Estadual de Londrina, Londrina, Brazil
}

Received 30 October 2013; revised 9 December 2013; accepted 22 December 2013

Copyright (c) 2014 Fernanda Corrêa da Silva Vasconcellos et al. This is an open access article distributed under the Creative Commons Attribution License, which permits unrestricted use, distribution, and reproduction in any medium, provided the original work is properly cited. In accordance of the Creative Commons Attribution License all Copyrights (C) 2014 are reserved for SCIRP and the owner of the intellectual property Fernanda Corrêa da Silva Vasconcellos et al. All Copyright (C) 2014 are guarded by law and by SCIRP as a guardian.

\section{ABSTRACT}

Bacterial spot caused by Xanthomonas arboricola pv. pruni (Xap) is considered as a major problem in peach orchards. Copper and antibiotics are used to control, and biocontrol should be a new alternative with low environment impact. The objective was evaluated by the antibiotic activity of the metabolite produced by Pseudomonas aeruginosa LV strain. The free cells supernatant was fractionated with a serial organic solvent with crescent polarity and a dichloromethane phase was concentrated and lyophilised, and after was fractionated using vacuum liquid chromatography. The antibiotic activity of the F3 fraction containing an organometallic compound was tested on Xap in vitro and in a greenhouse conditions. Plants were sprayed with F3 before or after Xap infection and the results showed changes in exopolysaccharides and cell morphology. The F3 concentration of $450 \mu \mathrm{g} \cdot \mathrm{mL}^{-1}$ was more effective. The results showed that F3 fraction could be a new alternative to control bacterial spot.

\section{KEYWORDS}

Peach Tree; Bacterial Spot; Biological Control;
Leaf Lesions; Xanthomonas arboricola Pv. pruni

\section{INTRODUCTION}

Bacterial spot is a disease of peach trees (Prunus persica L. Batsch) caused by Xanthomonas arboricola pv. pruni [1]. It is considered an important disease, especially when environmental conditions are favourable, such as high humidity and temperature. The symptoms of bacterial spot are characterised by brown or purple aqueous spots, which dry up and fall causing perforations in leaves, with a consequent weakening and premature defoliation of the plant, thereby causing its death [2].

Products based on copper can control bacterial spot, such as copper hydroxide, copper oxychloride and cuprous oxide [3]. Sometimes copper compounds are mixed with antibiotics such as streptomycin or oxytetracycline to control bacterial spot [4]. However, the use of this method could select resistant pathogens, causing outbreaks of disease, a reduction in beneficial microorganisms and harm to humans, animals and the environment because of the residue accumulation in soil, water and food [5].

Biological control is an alternative to increase the sustainability of agriculture and decrease the impact on nontarget organisms. The most important bacterial genera used as biocontrol agents are Bacillus and Pseudomonas, 
which produce many bactericidal compounds [6,7], and the application of antagonistic bacterial products can provide the effective control and management of bacterial spot [5].

The Pseudomonas sp. has been used as a biopesticide at the USA since the 1990 as an attractive strategy for biologically controlling plant diseases [8]. Products derived from several Pseudomonas species are currently registered with the US Environmental Protection Agency and are commercially available to producers as biopesticides [9]. Therefore, the aim of biological control is to reduce the damage caused by the phytopathogens in the plant, and the wide distribution of the Pseudomonas sp. with antagonist activity might help develop specific strategies for biological control [10].

Thus, it is important that researchers find effective agents and demonstrate their effectiveness to show growers the benefits to gain their support and thereby ensure that the reduction of pesticides can become reality [11]. Since research in the greenhouse can offer success in the biological control of the phytopathogens, the knowledge obtained from this system can assist in the transition to the field [12].

The metabolite used as the biological control in this study is produced by the Pseudomonas aeruginosa LV strain. This bacteria was isolated from the lesions of citrus canker where many bacteria compete for nutrients and space, and produce antibiotic compounds against $X$. axonopodis pv. citri, the phytopathogenic bacterial agent that causes the citrus canker [13].

The Laboratory Microbial Ecology group has worked with the Pseudomonas sp. for ten years to isolate, purify and identify the metabolite molecule and test it against diseases caused by different species Xanthomonas plants such as Citrus sinensis cv. Valence, Eucalyptus sp., Phaseolus vulgaris. The control of bacterial spot in $P$. persica $\mathrm{cv}$. Maciel by F3 fraction appears as a new alternative to decrease the incidence of this disease and losses by growers. Therefore, the aim of this study is to evaluate the antibiotic activity of the metabolite produced by the $P$. aeruginosa. against $X$. arboricola pv. pruni.

\section{MATERIALS AND METHODS}

\subsection{Bacterial Strains}

The bacteria strain used in the experiments was $X$. $a r$ boricola pv. pruni (Xap). This was kindly provided by $\mathrm{Dr}$ Bernardo Ueno (EMBRAPA Clima Temperado, Pelotas, Brazil), whereas the Pseudomonas sp. strain LV metabolite producer was from our own collection [12]. The strains were stored in a 30\% glycerol solution and kept in liquid nitrogen. These strains have been used in many experiments to test the disease control caused by other
Xanthomonas species in different plants. The F3 fraction was chosen because it showed a high inhibition halo in antibiosis experiments against many Xanthomonas species.

\subsection{Production and Purification of Antibiotic Substances}

The method of production has been patented (Patent \#PI0803350-1; www.inpi.gov.br). Metabolite production was obtained from the culture of Pseudomonas aeruginosa $\left(10^{8} \mathrm{CFU} \cdot \mathrm{mL}^{-1}\right)(\mathrm{O} . \mathrm{D} .=0.09, \lambda=590 \mathrm{~nm})$ where $150 \mu \mathrm{L}$ of this suspension was inoculated in $1.5 \mathrm{~L}$ of nutrient broth plus copper chloride $\left(\mathrm{CuCl}_{2} \cdot 2 \mathrm{H}_{2} \mathrm{O} ; 150 \mathrm{mg}\right.$. $\mathrm{L}^{-1}$ ) and incubated at $28^{\circ} \mathrm{C}$ for 15 days at $100 \mathrm{rpm}$ in a horizontal shaker. After that, the culture was centrifuged (9000 rpm, $20 \mathrm{~min}^{-1}, 4^{\circ} \mathrm{C}$ ) and the free cells supernatant were treated with dichloromethane $1: 1(\mathrm{v}: \mathrm{v})$ in a separation funnel in aliquots of $500 \mathrm{~mL}$ of supernatant plus solvent. For each separation, this procedure was repeated 10 times, shaken once for $30 \mathrm{~s}$ and left to rest for $15 \mathrm{~min}$. The dichloromethane phase (DP), which was obtained in the partition, was concentrated in a rota-evaporator under reduced pressure $\left(10 \mathrm{~L}\right.$ at $\left.45^{\circ} \mathrm{C}\right)$, frozen in liquid nitrogen and lyophilised for $24 \mathrm{~h}$. The amount obtained was around $0.5 \mathrm{~g}$ of the DP per $15 \mathrm{~L}$ of supernatant.

\subsection{Vacuum Liquid Chromatography (VLC) of the DP}

The DP was fractionated by VLC in a glass column (20 mm $\Phi \times 350 \mathrm{~mm}$ high) attached to a vacuum pump (51 kPa). The column was filled with $30 \mathrm{~g}$ of silica gel 60 , and $2 \mathrm{~g}$ of the DP was mixed with $5 \mathrm{~g}$ of silica gel. For the passages in the organic solvents, hexane, dichloromethane and ethyl acetate at 1:1 (v:v) were used in aliquots of $40 \mathrm{~mL}$ with 10 repetitions for each solvent. Three fractions were then obtained: the hexane fraction (F1), dichloromethane fraction (F2) and ethyl acetate fraction (F3). The fractions were concentrated in a rotaevaporator under reduced pressure at $45^{\circ} \mathrm{C}$, frozen in liquid nitrogen and lyophilised.

\subsection{Evaluation of Antibiotic Activity of the in Vitro Tests}

All the experiments were repeated three times.

\subsubsection{Evaluation of the Antibiosis Effect of the Agar Diffusion Technique on Xap}

The antibiotic activity of the F3 fraction was evaluated by the diffusion method in agar (pour plate). Aliquots of $1000 \mu \mathrm{L}$ of Xap in log phase $\left(10^{8} \mathrm{CFU} / \mathrm{mL}\right)$ (O.D. $=0.37$, $\lambda=590 \mathrm{~nm}$ ) were placed in Petri dishes with nutrient agar. Afterwards, wells were made of $9 \mathrm{~mm} \Phi$ on agar. Aliquots of $150 \mu \mathrm{L}$ of the F3 fraction were added into the 
wells at concentrations of 1000, 100 and $50 \mu \mathrm{g} \cdot \mathrm{mL}^{-1}$, and sterile distilled water was used as a negative control (solvent used in the suspension of the F3 fraction). The experiment was conducted with three concentrations of F3 and three replicates $(3 \times 3, n=9)$ and respective control. The plates were incubated at $28^{\circ} \mathrm{C} / 48 \mathrm{~h}$, and inhibition halos were evaluated (mm). The F3 fraction is semipurified and containg only one antimicrobial substance against Gram negative rods, that is an organometallic compound.

\subsubsection{Determination of the Minimum Inhibitory Concentration (MIC)}

The MIC was carried out in plates of cell culture with 24 wells and six concentrations of the F3 fraction with four replicates per concentration $(100 ; 50 ; 25 ; 12.5 ; 6.25$; $3.12 \mu \mathrm{g} \cdot \mathrm{mL}^{-1}$ ). Wells with only nutrient broth as considered negative control and positive control as considered cells suspension of Xap in the log phase. In each well, there was added $1.8 \mathrm{~mL}$ of nutrient broth plus $100 \mu \mathrm{L}$ cell suspension of Xap and $100 \mu \mathrm{L}$ of the respective concentration of the F3 fraction. The plates were incubated at $28^{\circ} \mathrm{C} / 48 \mathrm{~h}$, and subsequently $20 \mu \mathrm{L} \mathrm{2,} \mathrm{3,} \mathrm{5-}$ triphenyltetrazolium chloride (TTC $1 \%$ ) was added and incubated at $28^{\circ} \mathrm{C} / 20 \mathrm{~min}$. The results were evaluated as sensible when the Xap showed non-growth (-no colour change) and resistant when Xap showed growth (+colour change to pink).

\subsubsection{Electron Microscopic Study}

The evaluation of antibiotic action of the F3 fraction in the cellular morphology of Xap was carried out with a concentration of the F3 fraction and three different incubation times (T1, T3 and T6 h). Control was with sterile distilled water (solvent used in the suspension of the F3 fraction). The inoculum of Xap was obtained from the liquid culture in the log phase. Aliquots of $100 \mu \mathrm{L}$ of the F3 fraction and distilled water control were added into tubes containing $10 \mu \mathrm{L}$ of nutrient broth with Xap and a concentration $\left(200 \mu \mathrm{g} \cdot \mathrm{mL}^{-1}\right)$ of the F3 fraction, and incubated for 1,3 and $6 \mathrm{~h}$ at $28^{\circ} \mathrm{C}$ in a horizontal shaker at $100 \mathrm{rpm}$.

Aliquots of $20 \mu \mathrm{L}$ of T1, T3 and T6 were transferred onto glass slides previously coated with poly-L-lysine and placed at $28^{\circ} \mathrm{C}$ for $1 \mathrm{~h}$ to dry. Slides were then fixed in a solution containing $2.5 \%$ glutaraldehyde, $2 \%$ paraformaldehyde in $0.1 \mathrm{M}$ sodium cacodylate buffer ( $\mathrm{pH}$ 7.2) for $12 \mathrm{~h}$. After being post-fixed in a solution in $\mathrm{OsO}_{4} 1 \%$ for $2 \mathrm{~h}$, the samples were dehydrated in an ethanol gradient 70, 80, 90 and $100^{\circ} \mathrm{GL}$ and completely dehydrated on a critical point dryer in $\mathrm{CO}_{2}$ (BALTEC CPD 030 Critical Point Dryer, UK). Afterwards, the slides were coated with gold (SDC BALTEC 050 Sputter Coater, UK). Finally, the samples were observed by scanning electron microscopy (FEI Quanta 200).

\subsection{Evaluation of the Antibiotic Activity of the F3 Fraction on the Lesion Formation on Leaves}

The experiment was repeated three times. Plants of $P$. persica cv. Maciel were kept in a greenhouse $\left(25^{\circ} \mathrm{C}\right)$ and watered with tap water when needed. The experiment had two application times for the F3 fraction (pre- and post-treatment), with three concentrations (50, 150 and $450 \mu \mathrm{g} \cdot \mathrm{mL}^{-1}$ ), with one positive control with Xap and one negative control with distilled water. All treatments and the respective controls were composed with four replicates. The F3 fraction was sprayed onto mature leaves selected for their similar aspect, size and colour. Before application, plants were covered for $24 \mathrm{~h} / 30^{\circ} \mathrm{C}$ with transparent plastic to form a moist chamber and facilitate the opening of the stomata. In the pre-treatment, the plants were sprayed with $10 \mathrm{~mL}$ of the F3 fraction per plant at concentrations of 50, 150 and $450 \mu \mathrm{g} \cdot \mathrm{mL}^{-1}$ and closed. After $24 \mathrm{~h}$, the plants were sprayed with a suspension of $10 \mathrm{~mL}$ of Xap (O.D. $=0.37, \lambda=590 \mathrm{~nm}$ ) per plant. After $24 \mathrm{~h}$, the moist chamber was removed from the plants. In the post-treatment, the same procedure described above was adopted except the order of the spraying, which was first inoculated to Xap and then sprayed with the concentrations of the F3 fraction. Then, $10 \mathrm{~mL}$ of distilled water was used in the controls for the pre- and post-treatment (solvent used to dilute the F3 fraction). The number of lesions was evaluated by counting the lesions on each plant for treatment after, and the data were submitted to regression $(p<0.05)$.

\section{RESULTS}

\subsection{Evaluation of Antibiotic Activity Using in Vitro Tests}

\subsubsection{Evaluation of the Antibiosis Effect on the Agar Diffusion Technique on Xap and MIC}

Two in vitro tests were carried out. The first one showed that it was most effective concentration was $1000 \mu \mathrm{g} \cdot \mathrm{mL}^{-1}$ (Table 1). The second experiment was evaluated the MIC, and showed that at $50 \mu \mathrm{g} \cdot \mathrm{mL}^{-1}$ no cellular activity was observed after applying TTC $1 \%$.

\subsubsection{Electron Microscopic Study}

Over time the cell ultrastructure changes until the total

Table 1. Evaluation of antibiosis effect of F3 fraction by agar diffusion technique on Xanthomonas arboricola pv. Pruni.

\begin{tabular}{cc}
\hline F3 fraction concentration $\left(\mu \mathrm{g} \cdot \mathrm{mL}^{-1}\right)$ & Halo $(\mathrm{mm})$ \\
\hline 1000 & 32.33 \\
100 & 19.33 \\
50 & 15.0 \\
\hline
\end{tabular}


collapse of bacterial cell. Using scanning electron microscopy, no changes were observed in non-treated cells after six hours (Figure 1(a)). In the cells treated after one hour, the exopolysaccharide almost disappeared but the cell morphology showed few changes (Figure 1(b)). After three hours, the complete absence of the exopolysaccharide was observed and the cell morphology was disarranged (Figure 1(c)). After six hours, the cell morphology was completely disarranged, showing more length cells and a cell wall with what looked like a hollow (Figure 1(d)).

\subsection{Evaluation of the Antibiotic Activity of the F3 Fraction on the Lesion Formation on Leaves}

After the effect observed in the in vitro experiments and the cell morphology under the scanning electron microscope, the next step was to study the influence of the F3 fraction on the lesion formation on peach leaves. This was carried out in greenhouse conditions with no large plants.

In plant experiments, three concentrations (50, 150 and $450 \mu \mathrm{g} \cdot \mathrm{mL}^{-1}$ ) were used in two different times: pretreatment before the F3 fraction and after Xap suspension and post-treatment before Xap and after the F3 fraction. In pre-treatment, significant differences were observed among all treatments compared with controls. Among the

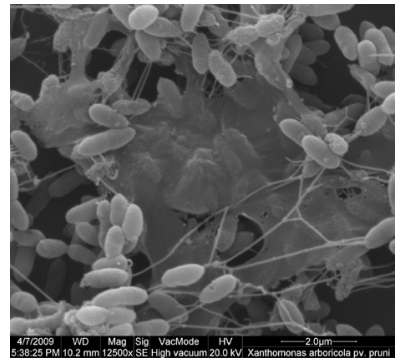

(a)

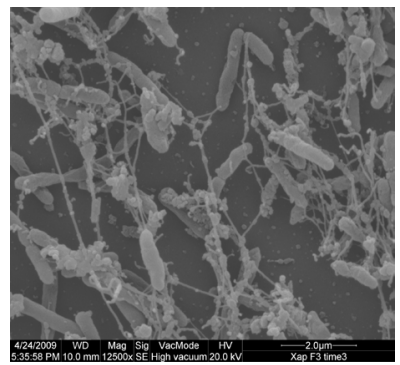

(c)

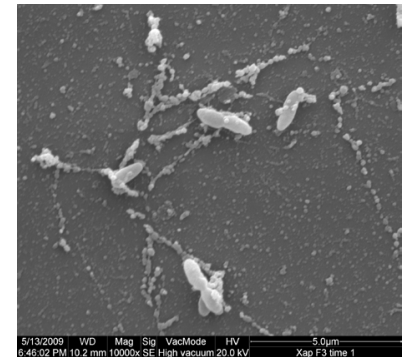

(b)

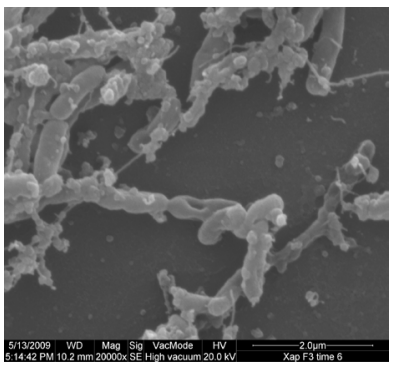

(d)
Figure 1. Scanning electron microscopic image of $X$. arboricola pv. pruni. Antibiotic activity and morphological changes in Xap treated with the F3 fraction $\left(200 \mu \mathrm{g} \cdot \mathrm{mL}^{-1}\right)$. A. Xap culture non-treated with the F3 fraction after $3 \mathrm{~h}$ incubation (12,500×); B) Xap culture after $1 \mathrm{~h}$ treated with the F3 fraction $(10,000 \times)$; C) Xap culture after $3 \mathrm{~h}$ treated with the F3 fraction $(12,500 \times)$; D) Xap culture after $6 \mathrm{~h}$ treated with the F3 fraction $(20,000 \times)$. concentrations no differences were observed between 150 and $450 \mu \mathrm{g} \cdot \mathrm{mL}^{-1}$ of the F3 fraction (Figure 2(A)). The same results were observed in the post-treatment, where all the concentrations showed significant differences with control plants and no difference was observed between the number of lesions in the plants treated with 150 and $450 \mu \mathrm{g} \cdot \mathrm{mL}^{-1}$ of the F3 fraction (Figure 2(B)).

Some phytotoxicity effects were observed in the high concentration spray. When this effect was compared among treatments we observed that it decreased when the concentration of the F3 fraction decreased. No difference was observed between the pre- and post-treatments (Figure 3).

\section{DISCUSSION}

There are few studies on the biological control of Xap but several studies have used a Pseudomonas sp. as a
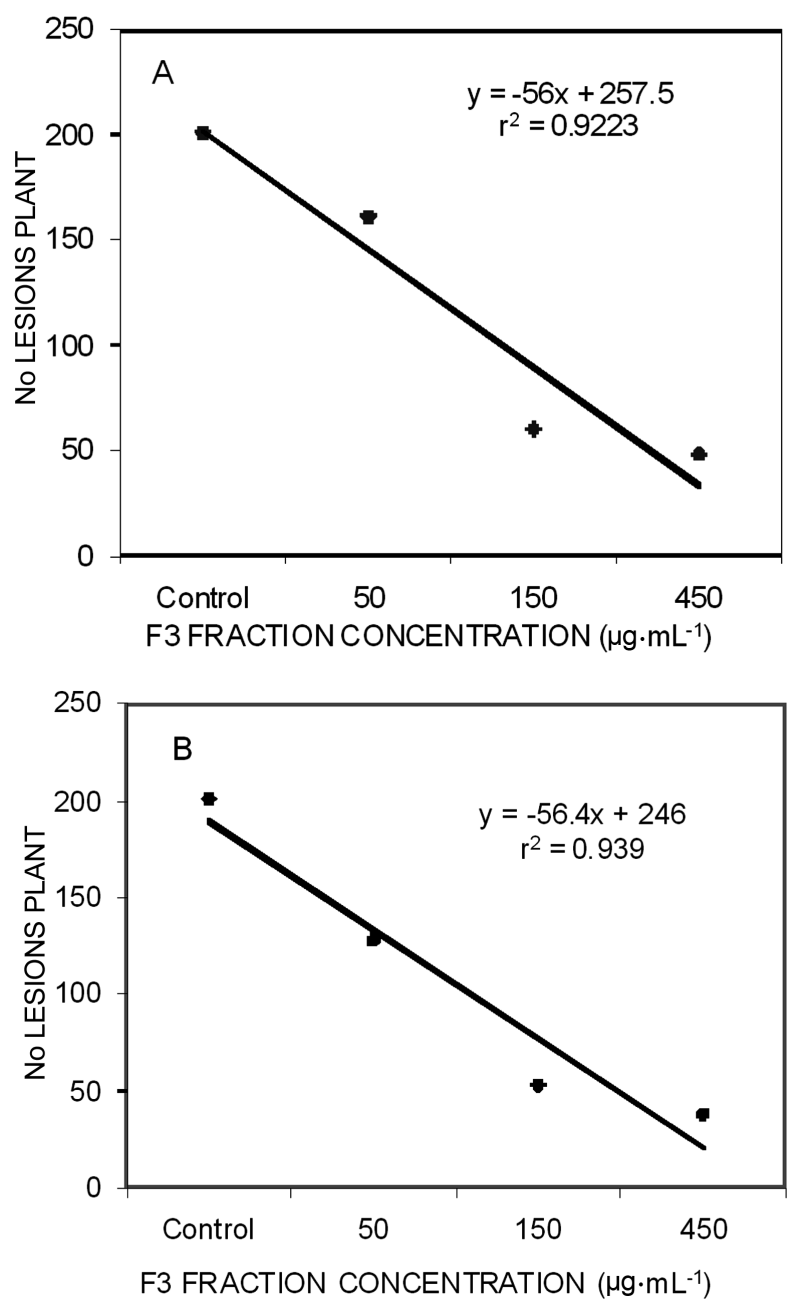

Figure 2. Correlation between dose effect $\left(50 \mu \mathrm{g} \cdot \mathrm{mL}^{-1}, 150\right.$ $\mu \mathrm{g} \cdot \mathrm{mL}^{-1}$ and $450 \mu \mathrm{g} \cdot \mathrm{mL}^{-1}$ ) and number of lesions formed by $X$. arboricola pv. pruni on peach leaves after 21 days of being sprayed. A) Pre-treatment with the F3 fraction; B) Post-treatment with the F3 fraction. 


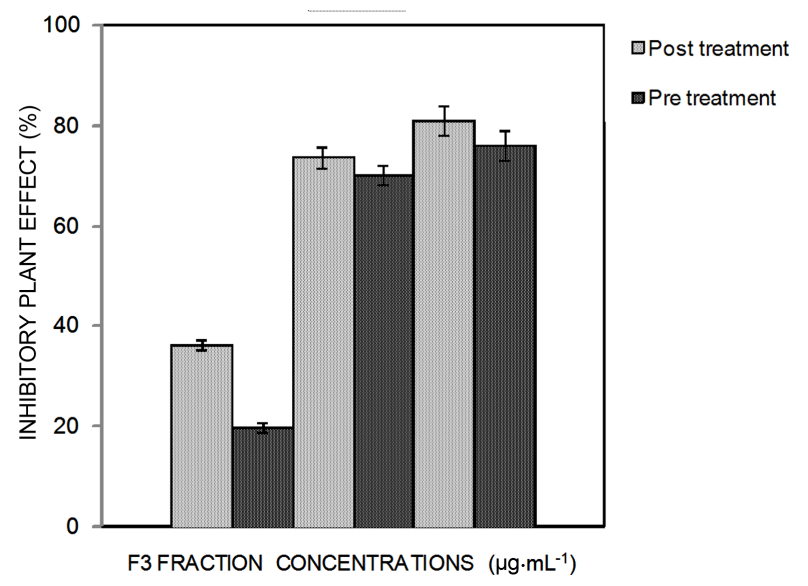

Figure 3. Inhibitory effect of the F3 fraction on the lesion formation of Xap on peach trees in pre- and post-treatment (50 $\mu \mathrm{g} \cdot \mathrm{mL}^{-1}, 150 \mu \mathrm{g} \cdot \mathrm{mL}^{-1}$ and $\left.450 \mu \mathrm{g} \cdot \mathrm{mL}^{-1}\right)$. The bars correspond to the standard deviation in each treatment $(p<0.05)$.

biological control agent to produce different antibiotic compounds that can be used to plant pathogenic fungi and bacteria [14]. According to [17], Gram negative bacteria are natural sources of compounds for biological control. These authors isolated several Gram-negative bacteria in rice seeds, with a predominance of Pseudomonas species such as $P$. resinovorans, $P$. putida B1, $P$. fluorescens, $P$. fulva and $P$. viridilivida that showed antagonism to fungi and bacteria. [8] suggest that the success to control phutopathogens is related with many factors such as: the occupation the same ecological niche, nutritional resources, the toleration of adverse conditions and reproduce under similar environmental conditions.

The in vitro experiments on the F3 fraction showed antibiotic effects in all tests, indicating that this fraction might help control bacterial spot. The effect of the F3 fraction on cell viability was confirmed in the ultrastructural study, which indicated that it is fast and effective against Xap and suggested that F3 shows a high potential to control Xap. Cells treated with the F3 fraction decreased exopolysaccharide production, which is essential for bacteria survival and colony organisation because it protects bacteria against desiccation and facilitates bacterial dispersal in host plants during infection [15].

Moreover, the in vivo experimental results showed that the highest concentration was the best to control bacterial spot both in the pre- and post-treatment. This means that application time had no influence on lesion formation control. However, the concentrations showed different effects. [13] Found that the F3 fraction decreased the lesion area of citrus canker leaves of $C$. sinensis cv. Valence caused by $X$. axonopodis pv. citri. Different effects were also observed. For example a smaller concentration was more effective in $X$. axonopodis pv. Citri, but in Xap we found that the effectiveness of the concentrations of
F3 was four times higher. The same author showed that lesion formation control is influenced by the pre- and post-treatment in contrast to our findings. However, these results suggest that there is a natural antagonism between bacteria with a high degree of genetic similarity and ecological niche, favouring the use of bacteria as a biological control agent against a phytopathogen [16].

In the field, experiments need to determine how this compound behaves and preserves the antibiotic effect in this condition to control Xap. In the greenhouse, all conditions help Xap infection and the establishment and lesion formation on leaves because the temperature and humidity were controlled.

When an effect on lesion formation by Xap is observed in this experimental condition, we suggest that the F3 fraction should be a new challenge on Xap control in the field. The phytotoxicity effect is another problem that needs to be solved. Finding the optimal concentration that does not cause phytotoxicity is essential for decreasing injury to peach trees, as occurred in this work. Many products used in biological control can cause phytotoxicity at the highest concentrations, although it depends on the plant species being used. Therefore, knowing the chemical properties and biological activity of the product can be a good biological control agent [18].

The present paper showed that the F3 fraction showed an antibiosis effect against Xap and disarranged the bacterial cell and exopolysaccharide formation. This suggests that it might be effective in the control of lesion formation on leaves by Xap, but further studies need to be carried out in field conditions.

\section{ACKNOWLEDGEMENTS}

We thank the National Council of Scientific and Technological Development $(\mathrm{CNPq})$ and Fundação Araucaria who enabled the execution of this study by conceding PIBIC, MSc., PhD and Productivity in research grants.

\section{REFERENCES}

[1] Vauterin, L., Hoste, B., Kersters, K. and Swings, J. (1995) Reclassification of Xanthomonas. International Journal of Systematic and Evolutionary Microbiology, 45, 472489. http://dx.doi.org/10.1099/00207713-45-3-472

[2] OEPP/EPPO (2006) EPPO Standard PM 7/64 Xanthomonas arboricola pv. pruni. OEPP/EPPO Bulletin, 36, 129133.

[3] Marco, G.M. and Stall, R.E. (1983) Control of bacterial spot of pepper initiated by strains of Xanthomonas campestris pv. vesicatoria that differ in sensibility to copper. Plant Disease, 67, 779-781.

http://dx.doi.org/10.1094/PD-67-779

[4] MacManus, P.S., Stockwell, V.O., Sundin, G.W. and Jones, A.L. (2002) Antibiotic use in plant agriculture. An- 
nual Review of Phytopathology, 40, 443-465. http://dx.doi.org/10.1146/annurev.phyto.40.120301.09392 $\underline{7}$

[5] Pagani, C., Silvera, E., Wallasek, W. and Solares, E. (1998) Advances in the identification at the moment on the major susceptibility of the fruit infection of peach tree. $\mathrm{Te}$ chnical Meeting about Fruit Trees Protection, National Research Institute of Agronomy, Uruguay, 37.

[6] Chu, G.X., Wakelin, S.A., Condron, L. and Stewart, A. (2010) Effect of soil copper on the response of soil fungal communities to the addition of plant residues. Pedobiologia, 53, 353-359. http://dx.doi.org/10.1016/j.pedobi.2010.04.002

[7] Shoda, M. (2000) Bacterial Control of Plant Diseases. Journal of Bioscience and Bioengineering, 89, 515-521. http://dx.doi.org/10.1016/S1389-1723(00)80049-3

[8] Lugtenberg, B. and Kamilova, F. (2009) Plant-growthpromoting rhizobacteria. Annual Review of Microbiology, 63, 541-556.

http://dx.doi.org/10.1146/annurev.micro.62.081307.16291 $\underline{8}$

[9] Stockwell, V.O. and Stack, J.P. (2007) Using Pseudomonas spp. for integrated biological control. Phytopathology, 97, 244-249.

http://dx.doi.org/10.1094/PHYTO-97-2-0244

[10] Gardener, B.B.M. (2007) Diversity and Ecology of Biocontrol Pseudomonas spp. in agricultural systems. Phytopathology, 97, 221-226.

http://dx.doi.org/10.1094/PHYTO-97-2-0221

[11] Battu, P.R. and Reddy M.S. (2009) Isolation of secondary metabolites from Pseudomonas fluorescens and its characterization. Asian Journal of Research in Chemistry, 2, 26-29.

[12] Rampazo, L.G.L. (2004) Evaluation of biological agents and their products on the incidence of canker citrus lesions on leaves. Londrina, Brasil, p. 67, (M.Sc. Dissertation. Departamento de Microbiologia. UEL. http://capesdw.capes.gov.br/capesdw/resumo.html?idtese $=20046440002012016 \mathrm{P3}$

[13] Oliveira, A.G., Murate, L.S., Spago, F.R., Lopes, L.P., Beranger, J.P.O., San Martin, J.A.B., Nogueira, M.A., Andrade, C.G.T.J, Mello, J.C.P. and Andrade, G. (2011) Evaluation of the antibiotic activity of extracellular compounds produced by the Pseudomonas strain against the Xanthomonas citri pv. citri 306 strain. Biological Control, 56, 125-131. http://dx.doi.org/10.1016/j.biocontrol.2010.10.008

[14] Haas, D. and Défago, G. (2005) Biological control of soil-borne pathogens by fluorescent pseudomonads. $\mathrm{Na}$ ture Reviews Microbiology, 3, 307-319. http://dx.doi.org/10.1038/nrmicro1129

[15] Graham, J.H. Gottwald, T.R. Cubero, J. and Achor, D.S. (2004) Xanthomonas axonopodis pv. citri: Factors a Vecting successful eradication of citrus canker. Molecular Plant Pathology, 5, 1-15. http://dx.doi.org/10.1046/j.1364-3703.2004.00197.x

[16] Mercado-Blanco, J. and Bakker, P.A.H.M. (2007) Interactions between plants and beneficial Pseudomonas spp. exploiting bacterial traits for crop protection. Antonie van Leeuwenhoek, 92, pp. 367-389. http://dx.doi.org/10.1007/s10482-007-9167-1

[17] Xie, G., Soad, A., Swings, J. and Mew, T.W. (2003) Diversity of Gram negative bacteria antagonistic against major pathogens of rice from rice seed in the tropic environment. Journal of Zhejiang University SCIENCE, 4, 463-468. http://dx.doi.org/10.1631/jzus.2003.0463

[18] Rimando, A.M. and Duke, S.O. (2003) Natural products for pest management. Pest Management Science, 59, 708-717. 